\title{
Pleural sarcoidosis: one case presenting with an eosinophilic effusion
}

\author{
D VITAL DURAND, A DELLINGER, C GUERIN, JC GUERIN, R LEVRAT
}

\author{
From the Centre Hospitalier Lyon Sud, France
}

\begin{abstract}
Pleural manifestations are rare in sarcoidosis, occurring in about $1 \%$ of a cumulative series.' ${ }^{1}$ They include pleural effusions, pleural thickening, and spontaneous pneumothorax. We present a case of pleural sarcoidosis presenting as an eosinophilic effusion. Specific pleural lesions were established by thoracoscopy and biopsy, which showed appearances suggesting serous dissemination of sarcoid granulation tissue.
\end{abstract}

\section{Case report}

A 20 year old man was first admitted to hospital on 8 February 1982, because of left scapular pain and a dry cough. He had noted weight loss of $4 \mathrm{~kg}$ and increasing malaise over the past month. He denied night sweats and fever. He had no previous medical history and a chest radiograph seven months earlier for routine purposes showed normal appearances.

On examination, the only abnormal findings were diminished breath sounds and dullness to percussion at the left base. A chest radiograph showed bilateral hilar and paratracheal lymph node enlargement, a diffuse interstitial pulmonary infiltrate, and a left pleural effusion (fig 1). The erythrocyte sedimentation rate (ESR) was $92 \mathrm{~mm}$ in one hour (Westergren); the haemoglobin (Hb) concentration was $13.2 \mathrm{~g} / \mathrm{dl}$; the white blood count (WBC) $13 \times 10^{9} / 1$ ( $4 \%$ eosinophils); platelets $545 \times 10^{9} / \mathrm{l}$; serum calcium concentration $2.26 \mathrm{mmol} / \mathrm{l}(9.04 \mathrm{mg} / 100 \mathrm{ml})$. Serum angiotensin converting enzyme activity was $34 \mathrm{nmol} / \mathrm{ml}$ min (normal lower limit $40 \mathrm{nmol} / \mathrm{ml} / \mathrm{min}$ ). An intradermal tuberculin test (50 units IP 48, Institut Pasteur) gave a negative reponse. No tubercle bacilli were isolated from the many sputum samples examined. Serological studies for parasitic infection gave negative results.

Pulmonary function tests showed a forced vital capacity of 3.51 (predicted $4 \cdot 1 \mathrm{l}$ ), $\mathrm{FEV}_{1} 71 \%$ (predicted $83 \%$ ), and transfer coefficient (Kco) $5 \cdot 1 \mathrm{~min}^{-1}$ torr $^{-1}$ (predicted 5.9) (1.7 $\mathrm{mmol} \mathrm{min}^{-1} \mathrm{kPa}^{-1} \mathrm{l}^{-1}$ (predicted 2.0)). Pleural aspiration yielded $50 \mathrm{ml}$ of clear yellow fluid with a protein content of $52 \mathrm{~g} / \mathrm{l}$. Microscopy showed the fluid to be profusely cellular; the white cell differential count was $2 \%$ neutrophils, $90 \%$ eosinophils $(76 \%$ at subsequent thoracocentesis), $4 \%$ basophils, $3 \%$ lymphocytes, and $1 \%$ mesothelial cells; bacterial cultures were negative. Fibreoptic bronchoscopy and bronchial biopsy specimens were

Address for reprint requests: Dr D Vital Durand, Centre Hospitalier Lyon Sud (Service Pr R Levrat), 69310 Pierre Benite, France.

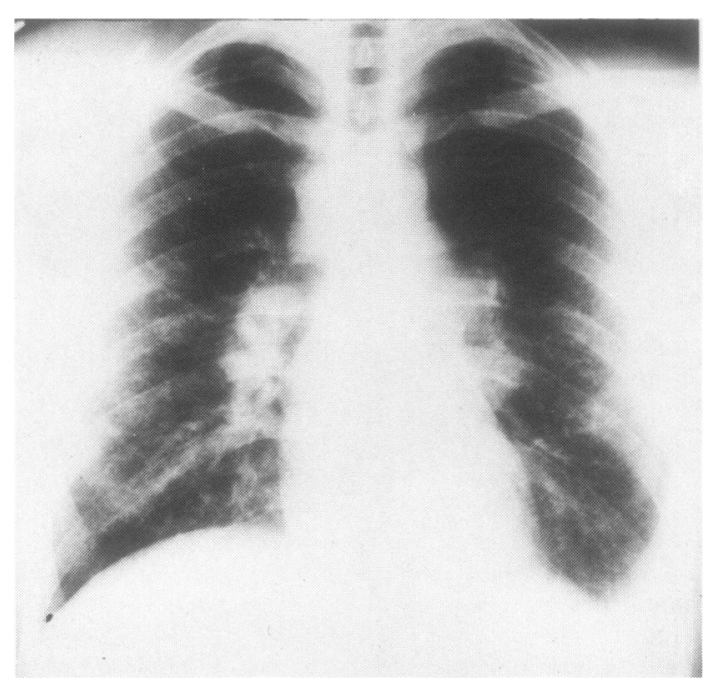

Fig 1 Chest film on admission showing bilateral hilar nodes, diffuse interstitial infiltrate, and a left pleural effusion.

normal. Bronchoalveolar lavage fluid contained $56.75 \times$ $10^{6} \mathrm{cells} / \mathrm{ml}$ (normal $10 \pm 4 \times 10^{6} \mathrm{cells} / \mathrm{ml}$ ), with $22 \%$ lymphocytes, $1 \%$ polymorphonuclear cells, and $77 \%$ macrophages; angiotensin converting enzyme bronchial activity was $\mathbf{0 . 2 2} \mathrm{nmol} / \mathrm{ml} / \mathrm{min}$ (normal lower limit $\mathbf{0 . 3 0}$ $\mathrm{nmol} / \mathrm{ml} / \mathrm{min}$ ). Mediastinoscopy showed greatly enlarged lymph nodes. Histological examination showed follicular epithelioid and giant cell granulomas. All cultures and special stains were negative. A provisional diagnosis of thoracic sarcoidosis was made and the patient was discharged without any treatment.

On 14 April 1982 a chest radiograph showed resolution of the left sided pleural effusion but the appearances were otherwise unchanged. On 3 May 1982 a chest radiograph showed an asymptomatic pleural effusion on the right. On examination no other abnormality was observed. The ESR was $55 \mathrm{~mm}$ in one hour; $\mathrm{Hb} 14.4 \mathrm{~g} / \mathrm{dl}$; WBC $9.6 \times 10^{9} / 1$ ( $15 \%$ eosinophils). The results of further investigations for tuberculosis and parasitic infection were again negative. Serum angiotensin converting enzyme activity was 31 $\mathrm{nmol} / \mathrm{ml} / \mathrm{min}$. Thoracoscopy showed that the pleural surface was very inflamed and there were multiple adhesions. Small whitish granulations were observed on the parietal pleura (fig 2). The pleural fluid was yellow with a protein concentration of $56 \mathrm{~g} / \mathrm{l}$; the white cell differential count 


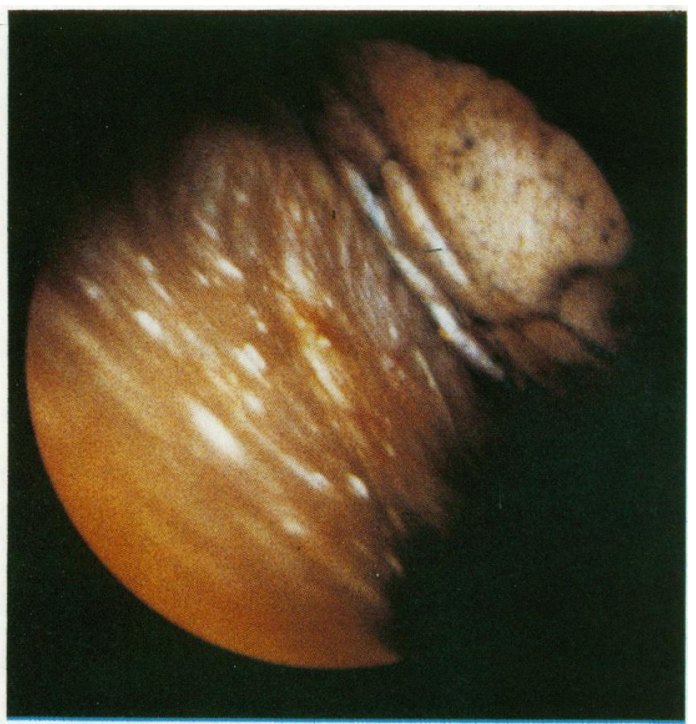

Fig 2 Thoracoscopic aspect showing multiple whitish granulations on the parietal serous membrane.

showed $1 \%$ neutrophils, $40 \%$ eosinophils, $3 \%$ basophils, $44 \%$ lymphocytes, and $2 \%$ mesothelial cells. Microscopic examination of pleural biopsy material showed multiple inflammatory granulomas with a few epithelioid and giant cell follicles. All cultures were negative. No treatment was prescribed and one month later a chest radiograph showed the resolution of the pleural effusion. In May 1983 the patient was doing well; all radiographic abnormalities had resolved.

\section{Discussion}

Pleural manifestations in the course of sarcoidosis have been recognised as an infrequent ${ }^{2}$ and perhaps underdiagnosed $^{3}$ manifestation of sarcoidosis. Three radiographic presentations are described: spontaneous pneumothorax, ${ }^{4}$ pleural thickening, and pleural effusions. ${ }^{256}$ The frequency of occurence of these last two manifestations in sarcoidosis has been reported to be from $1 \%^{1}$ to $10 \% .^{2}$ Sarcoid pleural effusion may be occasionally induced by mediastinal venous compression'; more often specific pleural lesions may be established by the presence of noncaseating granulomas. Thoracoscopy might increase substantially the proved incidence of pleural lesions in sarcoidosis.

We found only 32 previous reports of histologically proved pleural sarcoidosis with effusion. Analysis of the principal data where they are recorded showed that the average age was 35 years. There was no preference for side and in almost a third of reports effusions were bilateral. Pleural fluid was considered to be more often an exudate than a transudate. Cytological examination of pleural fluid showed scanty cells in half the cases; in the others lymphocytes were predominant (61-100\%). Our patient was exceptional, having $80 \%$ eosinophils in the fluid from the left side and $40 \%$ in that from the right side on the first tap. Three other cases are reported with pleural eosinophilia: Berte $^{8}$ found $29 \%$ eosinophils at the sixth thoracentesis; Beekman' found $15 \%$ eosinophils in the first pleural aspirate. In a further case ${ }^{6}$ the percentage was not specified. Although eosinophilia in the blood is well recognised, 9 the present case appears to be the first reporting the presence of eosinophilia in the pleural space and in the blood, although it was not present in the bronchoalveolar lavage fluid. Histological confirmation of sarcoid pleural granulomas was most often obtained by transparietal needle biopsy (18 patients) and an open biopsy was carried out in nine patients. Pleural effusion occurred at the time the patient first presented with sarcoidosis in five cases; in three of them, this was the sole radiological abnormality. In eight others pleural effusion developed during the first year of the disease. In five patients the interval between the initial diagnosis of sarcoidosis and the appearance of effusion varied from three to 17 years. Since most of the patients were given corticosteroids, the natural history of pleural effusion in sarcoidosis remains uncertain; complete resolution was usually reported, but progression to chronic pleural thickening also occurred.

\section{References}

' Chusid EL, Siltzbach LE. Sarcoidosis of the pleura. Ann Intern Med 1974;81:190-4.

${ }^{2}$ Wilen SB, Rabinowitz JG, Ulreich S, Lyons HA. Pleural involvement in sarcoidosis. Am J Med 1974;57:200-9

${ }^{3}$ Nickerson DA. Boeck's sarcoid. Report of six cases in which autopsies were made. Arch Pathol 1937;24:19-29.

${ }^{4}$ Herman DP, Carette MF, Mayaud C, Vannier R, Akoun G. Pneumothorax spontané et sarcoidose. Ann Med Intern (Paris) 1982; 133:641(abstract).

${ }^{5}$ Beekman JF, Zimmet SM, Chun BK, Miranda AA, Katz S. Spectrum of pleural involvement in sarcoidosis. Arch Intern Med 1976;136:323-30.

- Nicholls AJ, Friend JAR, Legge JS. Sarcoid pleural effusion: three cases and review of the literature. Thorax 1980; 35:277-81.

7 Tavaheri S, Hales CA. A cause of innominate obstruction and massive pleural effusion. Lung 1980;157:81-5.

${ }^{8}$ Berte SJ, Pfotenhauer MA. Massive pleural effusion in sarcoidosis. Am Rev Respir Dis 1962;86:261-4.

9 Mayock RL, Bertrand P, Morrison CE, Scott JH. Manifestations of sarcoidosis. Analysis of 145 patients, with a review of nine series selected from the literature. Am J Med 1963;35:67-89. 